КАРПОВА Дарья Ришатовна - студент второго курса магистратуры направления подготовки «Политология» ФГБОУ ВО МГЛУ (453120, Россия, 119034 Москва, ул. Остоженка, 38, с. 1; soydariakarpova@gmail.com)

\title{
ВКЛАД ДОБРОВОЛЬЧЕСКОГО ДВИЖЕНИЯ В РАЗВИТИЕ ГОСУДАРСТВА
}

\begin{abstract}
Аннотация. Статья посвящена развитию добровольческого движения в Российской Федерации, его влияния на различные сферы жизнедеятельности социума и государства, а также вклад волонтерства в развитие гражданского общества. Кроме того, автором на основании исследований рассматривается эффект добровольческой деятельности на мировую экономику и экономику отдельных стран

Ключевые слова: добровольческое движение, волонтерство, влияние добровольчества, молодежная политика
\end{abstract}

B олонтерское движение в России получило толчок к своему развитию в начале 90-х годов прошлого века, с развалом Советского Союза. Условия зарождающихся рыночных отношений, демократического управления, идеологического вакуума и неэффективного администрирования государственными структурами привели к появлению новых форм самоорганизации граждан, в том числе к образованию добровольческого движения и некоммерческого «третьего» сектора. В силу кризиса в стране начинают появляться первые неправительственные организации (НКО), объединяющие людей для решения существующих проблем. Возникает первый масштабный опыт организованного добровольчества в г. Москве, г. Санкт-Петербурге, когда десятки тысяч добровольцев участвуют в оказании помощи нуждающимся людям. В частности, когда в 1990 г. резко ухудшилось социально-экономическое положение страны, в Москве были объединены усилия около 6 тысяч добровольцев, которые помогали распространять гуманитарную помощь, поступавшую из-за рубежа. Количество благополучателей составило более 400 тысяч человек [Бодренкова 2010].

Стоит отметить, что ввиду отсутствия системной государственной поддержки, долгое время добровольческое движение существовало автономно и опиралось исключительно на энтузиазм, идеи, ценности и цели непосредственных участников волонтерского сообщества. По данным Всероссийского центра изучения общественного мнения (ВЦИОМ), одними из причин, почему люди занимаются добровольческой деятельностью, являются уважение, которым пользуются добровольцы у соотечественников, возможность самовыражения, а также использование добровольчества как способа решения проблем общества.

Однако в последнее время развитие добровольческого движения в Российской Федерации получает обширную поддержку со стороны государства. Так, согласно Распоряжению Правительства Российской Федерации от 29 ноября 2014 г. № 2403-р, формирование системы поддержки молодежной добровольческой (волонтерской) деятельности является одним из основных направлений государственной молодежной политики.

Правительством Российской Федерации утверждены Концепция развития добровольчества (волонтерства) в Российской Федерации до 2025 года и План мероприятий по реализации Концепции; 2018 год был объявлен Годом добровольца в Российской Федерации.

Также особое внимание развитию волонтерства в стране уделяет Президент 
Российской Федерации. Согласно Указу Президента Российской Федерации от 21.07.2020 № 474 «О национальных целях развития Российской Федерации на период до 2030 года», одним из показателей достижения национальных целей до 2030 года является увеличение доли граждан, занимающихся волонтерской (добровольческой) деятельностью или вовлеченных в деятельность волонтерских (добровольческих) организаций, до $15 \%$.

Глава государства регулярно подчеркивает важность труда волонтеров в развитии государства и гражданского общества, лично встречается с волонтерами и благодарит их.

Подобное внимание обусловлено значительным влиянием труда волонтерского сообщества на развитие социальной и экономической сфер жизнедеятельности общества и государства.

Понятие «гражданское общество» неразрывно связано с понятиями «правовое государство» и «демократия». По мнению Т. Гоббса, Дж. Локка, Ш. Монтескье гражданское общество представляет негосударственную часть общественно-политической жизни, совокупность общественных отношений, формальных и неформальных структур, обеспечивающих условия политической деятельности человека, удовлетворение и реализацию разнообразных потребностей и интересов личности, социальных групп и объединений, в том числе и потребностей оказания помощи нуждающимся. Если переносить понимание понятия «гражданское общество» на современность, стоит говорить о том, что «гражданское общество» - это устойчивая система социальных отношений, определяющих общественные интересы, и возникающая на определенном, исторически обусловленном этапе развития социума. Это некая система ограничения всевластия государства, налаживания взаимодействия государства и общества, в результате чего изменяется и государство, и общество [Гражданское общество... 2008: 61]. В свою очередь, основой гражданского общества являются общественные институты, различные некоммерческие, правозащитные, экологические и другие организации, объединения, движения, в том числе и волонтерские. По мнению специалистов, именно добровольческая деятельность лежит в самой основе функционирования третьего сектора и является одной из наиболее существенных характерных его черт. Третий сектор стоит называть добровольческим, а не определять, как это до сих пор принято, через отрицание того, чем он не является (некоммерческий и неправительственный) [Автономов 2014].

В условиях глобализированного и развивающего невиданными темпами мира государство как институт, механизмы которого требуют определенного времени для подстраивания под постоянно меняющиеся условия реальности, не всегда способно адекватно и вовремя реагировать на возникающие вызовы и проблемы. В такие моменты особенно остро обращает на себя внимание уровень вовлеченности граждан в разрешение проблем общества, на который прямым образом влияет развитие добровольчества. Подтверждением данного тезиса может служить всплеск участия граждан Российской Федерации в волонтерской деятельности во время развития новой коронавирусной инфекции. По официальным данным, более 20000 граждан приняли участие во Всероссийской акции взаимопомощи \#МыВместе, в рамках которой волонтеры развозили продукты и лекарства изолированным гражданам, оказывали психологическую, транспортную и другую помощь нуждающимся. Акция возникла как неорганизованное движение энтузиастов, однако была поддержана властями и бизнесом, что помогло ей приобрести федеральный масштаб.

Помимо этого, волонтерство обладает такой важнейшей функцией, как способствование повышению уровня социальной мобильности в обществе, или 
же функция социального лифта. Волонтерский опыт помогает набрать необходимые квалификации и обрести полезные знакомства для трудоустройства, что позволяет работодателям учитывать наличие волонтерского опыта у соискателя при его приеме на работу, тем самым значительно облегчая поиск работы для студентов и выпускников образовательных учреждений.

Еще одной значимой функцией волонтерства является снятие общественной напряженности. Как уже говорилось выше, одной из мотиваций для участия людей в добровольческом движении является возможность самовыражения, что в значительной степени способствует удовлетворению личности - согласно иерархии потребностей А. Маслоу, хотя потребность в самоактуализации стоит в завершающей части пирамиды, удовлетворив хотя бы $40 \%$ данной потребности, личность испытывает счастье. Также исследовательница И. Блясова считает, что добровольчество выступает как одно из направлений профилактической работы с подростками, так как за счет своего значительного воспитательного потенциала способствует их самореализации, формированию социальной ответственности, гражданской активности, предупреждению правонарушений и таких социальных проблем, как рост детской преступности, безнадзорности, детского сиротства [Блясова 2014].

Кроме социальных эффектов, добровольчество оказывает положительное влияние на экономику государства. Хотя при занятии волонтерством личность ориентируется на альтруистические ценности и не ищет материальной выгоды, при этом затрачивая свои ресурсы, волонтерство можно считать особым видом занятости [Трохина 2012], и данное занятие приносит определенный результат (зачастую материальный), который возможно оценить в экономическом эквиваленте.

Зачастую сотрудничество органов власти различных уровней с некоммерческими организациями, на базе которых трудятся волонтеры, позволяет реализовать определенные программы в рамках нехватки финансирования, либо избежать дополнительных расходов. Как показывает мировой опыт, в условиях профицита бюджета ценность волонтерства как ресурса не уменьшается, т. к. даже в наиболее благополучных странах в социальной сфере стараются в большем масштабе реализовывать те направления, на которые уже были заложены статьи расходов в бюджете [Автономов 2014]. В некоторых странах волонтерский опыт учитывают в качестве трудового стажа, принимая во внимание, что для реализации добровольческой деятельности, особенно в определенных сферах (юридическая, медицинская, поисково-спасательная и т.д.), требуется высокий уровень профессиональной подготовки, что позволяет приравнять труд волонтера к труду специалиста этой же сферы, работающего за деньги.

В Российской Федерации на данный момент единый подход к учету результатов и определению эффекта на экономику добровольческой деятельности находится на стадии проработки, статус волонтера не закреплен в Трудовом кодексе, однако уже существует понимание, и ведутся определенные исследования по данному вопросу. Так, участие в добровольческой деятельности можно подтвердить личной волонтерской книжкой (бумажной или электронной). Волонтерская книжка может стать дополнительной рекомендацией при трудоустройстве, поступлении в вуз или во время конкурса на крупные волонтерские мероприятия. Приказ Министерства образования и науки Российской Федерации (Минобрнауки России) от 14 октября 2015 г. N 1147 г. «Об утверждении Порядка приема на обучение по образовательным программам высшего образования - программам бакалавриата, программам специалитета, программам магистратуры» регулирует порядок учета добровольческой деятельности при поступлении в образовательные учреждения высшего образования; 
летом 2020 года были выпущены методические рекомендации по осуществлению учета добровольческой (волонтерской) деятельности в качестве индивидуального достижения при поступлении на обучение по программам высшего образования.

Зарубежный опыт подсчета волонтерского труда в экономику основывается на методе «восстановительной стоимости». Этот метод определяет трудовой потенциал добровольчества, сосредоточившись на ценности трудовых затрат. Более конкретно, этот подход фокусируется на ценности работы, которую выполняет доброволец [Хопкинс 2011]. Данный метод был рекомендован к использованию Международной организацией труда. Так, согласно данным Эндрю Г. Холдейна, главного экономиста и исполнительного директора департамента валютного анализа и статистики Банка Великобритании, каждый год формальные добровольцы (те, кто участвуют в мероприятиях через какую-либо организацию) выполняют объем работы, эквивалентный труду 1,25 млн сотрудников, получающих зарплату, что лишь немногим меньше 1,4 млн британцев, работающих в службе здравоохранения страны. Управление национальной статистики Великобритании подсчитало, что частая формальная добровольческая деятельность в 2012 году принесла стране около 24 миллиардов фунтов стерлингов экономического дохода. Это эквивалентно 1,5 \% ВВП страны. Добровольчество приносит в два раза больше пользы, чем сельское хозяйство, и примерно столько же, сколько телекоммуникационный сектор. Неформальное добровольчество (различные виды взаимопомощи и сотрудничества между отдельными людьми) может принести еще 19 миллиардов фунтов стерлингов дохода. С учетом нерегулярной волонтерской деятельности общий вклад данного явления в экономику страны достигает 50 миллиардов фунтов стерлингов, что примерно соответствует размеру энергетического сектора Великобритании. Стоит заметить, что приведенные цифры являются примерными, так как существуют барьеры для учета всей волонтерской деятельности в силу неформальной специфики данного явления (многие участники добровольческой деятельности никак не фиксируют и не регистрируют оказанные ими услуги).

Также согласно данным Управления национальной статистики Великобритании, незначительный спад волонтерского движения в стране на 7 \% в период с 2012 по 2015 год повлек за собой потерю более 1 миллиарда фунтов стерлингов дохода в национальный бюджет (при подсчете данных цифр учитывалось исключительно регулярное волонтерство, то есть деятельность людей, занимающихся формальным добровольчеством не реже, чем раз в месяц).

Подобные исследования проводились и в глобальном разрезе на выборке нескольких стран [Саламон, Соколовски, Хэддок, Тис 2012]. Результаты данного исследования показали, что волонтерский вклад в ВВП стран составляет от 0,1\% (Кыргызстан) до 2,7 \% (Норвегия). Среднее число по выборке из 16 стран составило $0,9 \%$.

По информации доклада «Волонтерство как потенциал развития здорового общества» исполнительного директора программы добровольцев Организации объединенных наций Тойли Курбанова на Петербургском международном экономическом форуме в 2018 г., до 1 млрд человек задействовано в добровольчестве в той или иной форме по всему миру. Но учитывая, что многие из них уделяют добровольчеству по несколько часов в день или по несколько дней в году, в переводе на эквивалент полной занятости можно говорить о 109 млн человек, которые занимаются добровольчеством на полную ставку, что также совпадает и с данными других исследований по учету волонтерской деятельно- 
сти [Хопкинс 2011]. Таким образом, вклад волонтеров в мировой ВВП составляет порядка $2,4 \%$.

Несмотря на тот факт, что зачастую экономический и социальный вклад волонтерской деятельности остается в значительной степени вне поля зрения широкой общественности, в Российской Федерации уже зародилось отношение к волонтерству как к важнейшему явлению жизни общества. Хотя методы учета и развития волонтерской деятельности в стране еще требуют доработки, нельзя не отметить, что данный вопрос постепенно появляется в политической и социальной повестке государства.

Статья публикуется при поддержке Школы молодого этнополитолога в Республике Башкортостан (грант Фонда президентских грантов 19-2-022447).

\section{Список литературы}

Автономов А. С. 2014. Добровольчество как фактор развития гражданского общества и социальных инноваций - Контуры глобальных трансформаций: политика, экономика, право. №6 (38). С. 92-109.

Бодренкова Г.П. 2010. Развитие добровольчества в Российской Федерации: опыт и перспективы, - СОТИС. № 5. С. 85-97.

Блясова И.Ю. 2014. Добровольческая деятельность - фактор предупреждения безнадзорности и правонарушений подростков, - Всероссийский научнопрактический журнал «Волонтер». № 1. С. 42-50.

Гражданское общество современной России. Социологические зарисовки с натуры (под ред. Е.С.Петренко). 2008. М.: Институт Фонда «Общественное мнение». $61 \mathrm{c.}$

Лестер, Саламон, Войжеч, Соколовски, Меган. 2011. Измерение экономической ценности волонтерской работы в глобальном масштабе: концепции, оценки и дорожная карта на будущее, - Annals of Public and Cooperative Economics, CIRIEC. C. 217-252.

Трохина А.В. 2012. Оценка трудового потенциала и экономических эффектов волонтерства, - Теория и практика общественного развития. № 12. С. 523-526.

Саламон, Соколовски, Хэддок, Тис. 2012. Состояние глобального гражданского общества и добровольчества: последние результаты внедрения руководства ООН по некоммерческим организациям в системе национальных счетов. M: CNP Working Paper № 49. 30 c.

\section{CONTRIBUTION OF THE VOLUNTARY MOVEMENT TO THE DEVELOPMENT OF THE STATE}

Abstract. The article is devoted to the volunteer movement development in the Russian Federation, its impact on various spheres of life of society and the state, as well as the contribution of volunteerism to the development of civil society. The author examines the effect of volunteerism on the world economy and the economy of different countries.

Keywords: voluntary movement, volunteerism, influence of volunteerism, youth policy 